\title{
SYNTHESIS AND STRUCTURE-ACTIVITY RELATIONSHIPS OF A NEW ORAL CEPHALOSPORIN, BMY-28100 AND RELATED COMPOUNDS
}

\author{
Takayuki Naito, Hideaki Hoshi, Shimpei Aburaki, Yoshio Abe, \\ Jun Okumura, Kozo Tomatsu and Hiroshi Kawaguchi \\ Bristol-Myers Research Institute, Ltd., Tokyo Research Center, \\ 2-9-3 Shimo-meguro, Meguro-ku, Tokyo 153, Japan
}

(Received for publication January 5, 1987)

\begin{abstract}
The synthesis and structure-activity relationships of 7-[D- $\alpha$-amino- $\alpha$-(4-hydroxyphenyl)acetamido]-3-[(Z)-1-propenyl]-3-cephem-4-carboxylic acid (BMY-28100) and its analogs in the 3- and 7-side chains are described. The 3-(substituted-propenyl) groups were introduced by the Wittig reaction of the 3-phosphoniomethyl cephems which were derived from the 3-chloromethyl derivatives. The reaction gave predominantly the cis isomer regarding the 3-side chain. The cis and trans isomers showed characteristic UV and ${ }^{1} \mathrm{H}$ NMR spectra. Most of cephems of this series were well-absorbed orally and more active both in vitro and in vivo than cephalexin and cefaclor against Gram-positive organisms. Their Gram-negative activity varied depending on the 3- and 7-substituents. Compounds with a cis-propenyl group showed the best Gram-negative activity among the 3-alkenyl analogs prepared, whereas the D-4-hydroxyphenylglycyl and D-4-hydroxy-3-methoxyphenylglycyl substitutions in the 7-side chain were found suitable to improve the Gram-negative activity of 3-cis-propenyl series of cephalosporins to the level favorably compared with that of cefaclor. The 3,4dihydroxyphenyl analog was found to be metabolized in vivo to the 4-hydroxy-3-methoxyphenyl derivative and, therefore, showed nearly the same in vivo activity as that of the latter. BMY-28100 was selected for further evaluation and the results will be reported in the subsequent paper.
\end{abstract}

Since cephaloglycin ${ }^{1,2)}$ was launched in 1965 , several oral cephalosporins have been developed for clinical use, such as cephalexin ${ }^{3)}$, cephradine ${ }^{4)}$, cefatrizine $^{5)}$, cefaclor $^{6)}$, cefroxadine $^{7)}$ and cefadroxil ${ }^{8)}$, which have a phenylglycyl (or its congener) or 4-hydroxyphenylglycyl group at the 7 position of cephalosporin nucleus. In our search for new orally active cephalosporins, we found that the 3-alkenyl derivatives of 7-phenylglycyl cephalosporins were well absorbed by oral administration. The representative member of this group is 7-[D- $\alpha$-amino- $\alpha$-(4-hydroxyphenyl)acetamido]-3-[( $Z$ )-1-propenyl]-3cephem-4-carboxylic acid designated as BMY-28100 (Fig. 1). This paper describes the synthesis and the structure-activity relationships of BMY-28100 and analogs ${ }^{\dagger}$.

\section{Synthesis}

BMY-28100 and its analogs were prepared by the synthetic route shown in Scheme 1 . The starting material, diphenylmethyl 7-amino-3chloromethyl-3-cephem-4-carboxylate $(\mathbf{1})^{\text {9) }}$, was acylated with $N$-tert-butoxycarbonyl (BOC)protected phenylglycines (2) in the presence of dicyclohexylcarbodiimide (DCC) to give the 7-

Fig. 1.

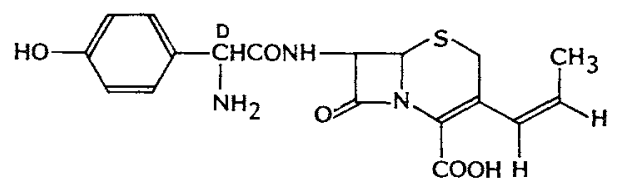

$\mathrm{BMY}-28100$

$t$ A part of this paper has been presented at the 14th Int. Congress of Chemother., Kyoto, 1985. 
Scheme 1.

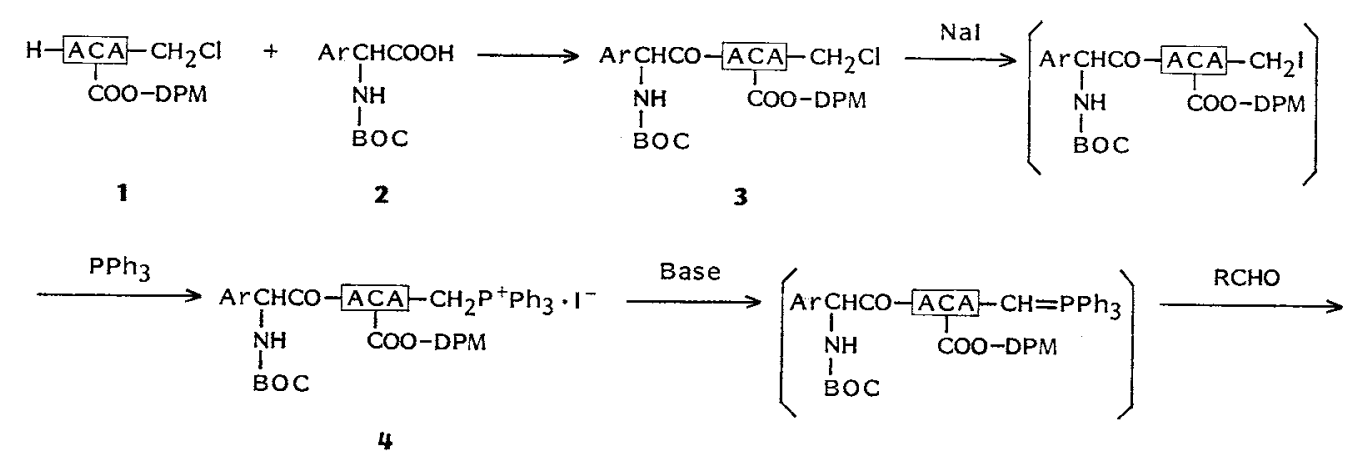

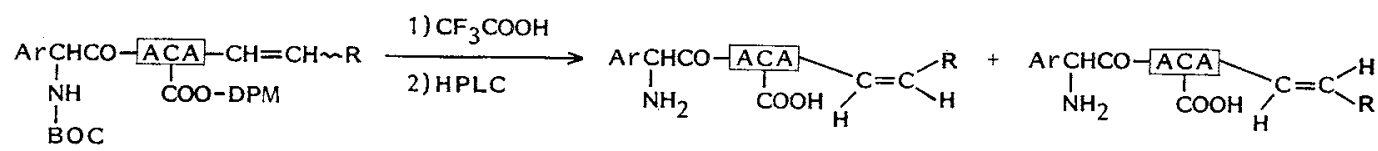

$$
\begin{aligned}
& 5 \\
& 6 \\
& 7 \\
& -\sqrt{A C A}-{ }_{0}^{-H N}-T_{0} \\
& \mathrm{BOC}=\operatorname{COOC}\left(\mathrm{CH}_{3}\right)_{3} \\
& D P M=\mathrm{CH}\left(\mathrm{C}_{6} \mathrm{H}_{5}\right)_{2}
\end{aligned}
$$

( $N$-BOC-phenylglycyl)-3-chloromethylcephalosporanates (3) in almost quantitative yield. The chlorides (3) were treated with $\mathrm{NaI}$ to afford the iodides, which were converted to the triphenylphosphonium iodides (4) by treating with triphenylphosphine. In most cases compounds 4 were prepared in one pot from 1 without isolation of the chlorides and iodides in about 60 to $90 \%$ overall yield (Table 1).

The Wittig reaction of 4 was performed with an appropriate aldehyde in dichloromethane or chloroform at room temperature in the presence of a base, such as sodium hydroxide, sodium carbonate or sodium bicarbonate. The reaction mixture was purified with a silica gel column to give the 3-alkenyl derivatives (5) in 20 to $80 \%$ yield (Table 2). As shown in the table, most of 5 showed a doublet vinyl proton signal with $J=11 \mathrm{~Hz}$ around $6.1 \mathrm{ppm}$ in their ${ }^{1} \mathrm{H}$ NMR spectra. This means that the Wittig reaction in this series of the compounds gave predominantly cis isomer regarding the 3-side chain. Although HPLC study indicated that 5 contained $15 \sim 20 \%$ of the trans isomer as a minor component, they were used for the next step without separation of the isomers.

Deblocking of 5 with trifluoroacetic acid (TFA) - anisole at room temperature gave crude TFA salts of the final products which were purified by reverse phase column chromatography to give a majority of the cis isomer (6) and the trans isomer (7) as a minor product.

When racemic phenylglycine derivatives were used in the 7- $N$-acylation, compounds 3 through 6 were obtained as a mixture of the corresponding diastereomers. In the final stage, the reaction products were subjected to reverse phase column chromatography to separate the $\mathrm{D}$ and $\mathrm{L}$ isomers regarding the $\alpha$-carbon in the 7-side chain, both of which having a cis configuration in the 3-side chain. In these cases the corresponding trans isomer could not be isolated because of a small amount of the isomer contained.

Table 3 summarizes the physico-chemical data of 6 and 7. The cis isomers (6) had an absorption maximum at ca. $280 \mathrm{~nm}$, whereas the trans isomers (7) exhibited the maximum at ca. $290 \mathrm{~nm}$ with greater 
Table 1. 3-Triphenylphosphoniomethylcephems (4).

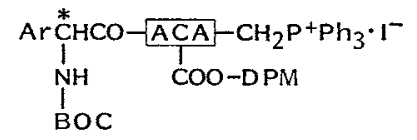

4

\begin{tabular}{|c|c|c|c|c|c|}
\hline Compound & $\mathrm{Ar}$ & * & $\begin{array}{c}\text { Yield } \\
\text { from } 1 \\
(\%)\end{array}$ & $\begin{array}{c}\mathrm{MP} \\
\left({ }^{\circ} \mathrm{C}, \mathrm{dec}\right)\end{array}$ & $\mathrm{UV} \lambda_{\max }^{\mathrm{MeOH}} \mathrm{nm}(\varepsilon)$ \\
\hline $4 a$ & & D & 85 & $160 \sim 165$ & $269(10,000), 276(9,600)$ \\
\hline $4 b$ & & $\mathrm{D}$ & 88 & $170 \sim 180$ & $269(10,600), 277(10,000)$ \\
\hline $4 c$ & & $\mathrm{DL}$ & 83 & $160 \sim 170$ & $269(11,000), 275(10,000)$ \\
\hline $4 d$ & & $\mathrm{D}$ & 58 & ca. 165 & $269(11,000), 276(12,000)$ \\
\hline $4 e$ & & $\mathrm{D}$ & 85 & ca. 170 & $269(12,000), 276(12,000)$ \\
\hline $4 f$ & & $\mathrm{D}$ & 86 & ca. 165 & $269(12,000), 277(12,000)$ \\
\hline $4 \mathrm{~g}$ & & $\mathrm{DL}$ & 58 & $160 \sim 165$ & $269(12,000), 276(13,000)$ \\
\hline $4 h$ & & $\mathrm{DL}$ & 82 & $165 \sim 170$ & $269(11,000), 277(11,000)$ \\
\hline $4 \mathbf{i}$ & & $\mathrm{DL}$ & 85 & $160 \sim 165$ & $269(10,000), 277(11,000)$ \\
\hline
\end{tabular}<smiles>CC1=CN2C(=O)C(NC=C3[Al]4C[As]34)C2SC1</smiles>

intensity in UV spectra than the corresponding cis isomers. Distinct differences between cis and trans isomers were also observed in their ${ }^{1} \mathrm{H}$ NMR spectra. As shown in Table 3, a vinyl proton closer to the cephem nucleus $\left(\mathrm{H}_{\mathrm{z}}\right.$ in Table 3$)$ of the cis isomers appeared at ca. $6.0 \mathrm{ppm}$ as a one-proton doublet with a coupling constant of $11 \mathrm{~Hz}$, whereas that of the trans isomers resonated at lower field (ca. $6.5 \mathrm{ppm}$ ) with a $16 \mathrm{~Hz}$ coupling constant. Another vinyl proton $\left(\mathrm{H}_{\mathrm{b}}\right)$ was obscure because of multiplicity due to coupling with neighboring aliphatic protons. The vinylic signal was confirmed by the decoupling study on the ${ }^{1} \mathrm{H}$ NMR of BMY 28100 (6d). When the allylic methyl proton at $1.71 \mathrm{ppm}$ was irradiated, a multiplet around $5.8 \mathrm{ppm}$ changed to a doublet with a coupling constant of $11 \mathrm{~Hz}$. On the other hand, the methyl signal was converted from a doublet to a singlet by irradiation at ca. $5.8 \mathrm{ppm}$. Change of multiplicity on the $\mathrm{H}_{\mathrm{a}}$ signal at $6.02 \mathrm{ppm}$, however, could not be detected because its chemical shift was close to the irradiated signal at $5.8 \mathrm{ppm}$.

Another difference between both isomers was observed in the signal of the $2-\mathrm{H}$ protons of the cephem nucleus. The resonance of the trans isomers (7) was observed at $c a .3 .6 \mathrm{ppm}$ as a two-proton 
Table 2. The Wittig reaction products (5).

$$
\begin{gathered}
\text { Ar } \stackrel{*}{1} \mathrm{HCO}-\stackrel{\mathrm{ACA}}{1}-\mathrm{CH}_{\mathrm{a}}=\mathrm{CH}_{\mathrm{b}} \sim \mathrm{R} \\
\stackrel{\mathrm{N}}{\mathrm{NH}} \text { COO-DPM } \\
1 \\
\text { BOC }
\end{gathered}
$$

5

\begin{tabular}{|c|c|c|c|c|c|c|c|}
\hline $\begin{array}{l}\text { Com- } \\
\text { pound }\end{array}$ & $\mathrm{Ar}$ & $\mathrm{R}$ & $*$ & $\begin{array}{l}\text { Yield } \\
(\%)\end{array}$ & $\begin{array}{c}\mathrm{MP} \\
\left({ }^{\circ} \mathrm{C}, \mathrm{dec}\right)\end{array}$ & $\frac{\mathrm{UV}}{\lambda_{\max }^{\mathrm{MeOH}} \mathrm{nm}(\varepsilon)}$ & $\begin{array}{c}{ }^{1} \mathrm{H}_{\mathrm{NMR}}^{\mathrm{a}} \\
\text { Vinyl-H } \\
(\delta, \mathrm{ppm}) \\
\end{array}$ \\
\hline $5 \mathbf{a}^{14\rangle}$ & & $\mathrm{H}$ & $\mathrm{D}$ & 79 & $c a .210$ & $295(14,000)$ & $6.90^{\mathrm{b}}$ \\
\hline $\mathbf{5 b}$ & & $\mathrm{H}$ & $\mathrm{D}$ & 45 & ca. 135 & $286(14,000)$ & ca. $7.0^{\mathrm{c}}$ \\
\hline $5 c$ & & $\mathrm{CH}_{3}$ & $\mathrm{D}$ & 34.5 & ca. 145 & $289(7,000)$ & 6.05 \\
\hline $5 d$ & & $\mathrm{CH}_{3}$ & $\mathrm{D}$ & 31 & $120 \sim 130$ & $283(8,300)$ & 6.07 \\
\hline $5 e$ & & $\mathrm{CH}_{3}$ & $\mathrm{DL}$ & 29 & ca. 120 & ND & 6.08 \\
\hline $5 \mathbf{f}$ & & $\mathrm{C}_{2} \mathrm{H}_{5}$ & $\mathrm{D}$ & 55 & ca. 115 & $277(10,000)$ & 6.06 \\
\hline $5 g$ & & & $\mathrm{D}$ & 21 & ND & ND & ND \\
\hline $5 \mathrm{~h}$ & & $\mathrm{CH}_{2} \mathrm{OCH}_{3}$ & D & 38 & ca. 115 & $278(8,000)$ & 6.18 \\
\hline $5 \mathbf{i}$ & & $\mathrm{CH}_{2} \mathrm{Ph}$ & $\mathrm{D}$ & 37 & ca. 120 & $277(8,600)$ & 6.15 \\
\hline $5 \mathbf{j}$ & & $\mathrm{CH}_{3}$ & $D$ & 21 & $120 \sim 125$ & $287(8,300)$ & 6.04 \\
\hline $5 k$ & & $\mathrm{CH}_{3}$ & $\mathrm{D}$ & 40 & $120 \sim 125$ & $282(9,800)$ & 6.04 \\
\hline $5 \mathbf{I}$ & & $\mathrm{CH}_{3}$ & $\mathrm{D}$ & 24.5 & $100 \sim 105$ & $282(9,900)$ & 6.08 \\
\hline $5 \mathrm{~m}$ & & $\mathrm{CH}_{3}$ & $\mathrm{DL}$ & 20 & $\mathrm{ND}$ & $282(8,500)$ & 6.10 \\
\hline $5 n$ & & $\mathrm{CH}_{3}$ & $\mathrm{DL}$ & 40 & ND & $280(9,800)$ & 6.08 \\
\hline 50 & & $\mathrm{CH}_{3}$ & DL & 37 & ND & $287(12,700)$ & 6.07 \\
\hline
\end{tabular}

a Determined in $\mathrm{CDCl}_{3} ; 1 \mathrm{H}, \mathrm{d}, J=11 \mathrm{~Hz}$.

b Determined in $\mathrm{CDCl}_{3}-\mathrm{DMSO}-d_{8} ; 1 \mathrm{H}$, dd, $J=17$ and $11 \mathrm{~Hz}$.

c $1 \mathrm{H}, \mathrm{m}$.

ND: Not determined.

singlet. This was also the case in 3-vinyl derivatives, $6 \mathrm{a}$ and $6 \mathrm{~b}$. On the contrary, that of the cis isomers appeared at 3.1 to $3.6 \mathrm{ppm}$ as an $\mathrm{AB}$ quartet with an $18 \mathrm{~Hz}$ coupling constant. This observation may reflect that the $2-\mathrm{H}$ protons of the trans isomers are magnetically equivalent, while those of the cis isomers are not equivalent because of the steric effect caused by the cis-substituent on the double bond of 
Table 3. BMY-28100 derivatives (6 and 7).
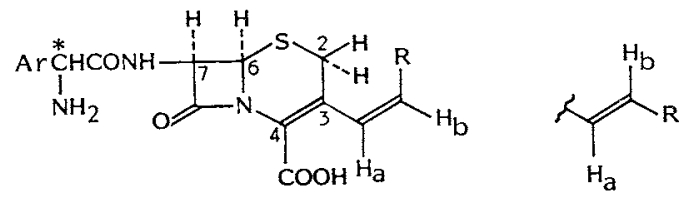

6

7

\begin{tabular}{|c|c|c|c|c|c|c|c|c|c|c|}
\hline \multirow{2}{*}{ Compound } & \multirow{2}{*}{$\mathrm{Ar}$} & \multirow{2}{*}{$\mathbf{R}$} & \multirow{2}{*}{$*$} & \multirow{2}{*}{$\begin{array}{l}\text { Yield } \\
(\%)\end{array}$} & \multirow{2}{*}{$\begin{array}{c}\mathrm{MP} \\
\left({ }^{\circ} \mathrm{C}, \mathrm{dec}\right)\end{array}$} & \multirow{2}{*}{$\mathrm{UV} \lambda_{\max } \mathrm{nm}(\varepsilon)^{\mathrm{a}}$} & \multicolumn{4}{|c|}{${ }^{1} \mathrm{H} \mathrm{NMR} \delta_{\mathrm{ppm}}$ in $\mathrm{D}_{2} \mathrm{O}\left(+\mathrm{NaHCO}_{3}\right)$} \\
\hline & & & & & & & $2-\mathrm{H}^{\mathrm{b}}$ & $6-\mathrm{H}^{c}$ & $7-\mathrm{H}^{\mathrm{c}}$ & Vinyl- $\mathrm{H}_{\mathrm{a}}{ }^{\mathrm{d}}$ \\
\hline $6 \mathbf{a}^{14)}$ & & $\mathbf{H}$ & $\mathrm{D}$ & 46 & $c a .190$ & $287(13,000)$ & $3.62(\mathrm{~s})$ & 5.20 & 5.75 & $7.3^{\mathrm{e}}$ \\
\hline $6 \mathrm{~b}$ & & $\mathbf{H}$ & $\mathrm{D}$ & 31 & ca. 190 & $283(14,000)$ & $3.60(\mathrm{~s})$ & 5.33 & 5.73 & $6.77^{f}$ \\
\hline $6 c$ & & $\mathrm{CH}_{3}$ & $\mathrm{D}$ & 60 & $c a .200$ & $282(8,800)$ & $3.12,3.48$ & 5.03 & 5.63 & 5.92 \\
\hline $6 d$ & & $\mathrm{CH}_{3}$ & $\mathrm{D}$ & 40 & $218 \sim 220$ & $279(9,800)$ & $3.27,3.59$ & 5.18 & 5.73 & 6.02 \\
\hline $7 d$ & & $\mathrm{CH}_{3}$ & $\mathrm{D}$ & 2 & ca. 230 & $292(16,900)$ & $3.60(\mathrm{~s})$ & 5.13 & 5.68 & 6.54 \\
\hline $6 e$ & & $\mathrm{CH}_{3}$ & $\mathbf{L}$ & 9 & ca. 200 & $279(9,900)$ & $3.36,3.67$ & 5.21 & 5.59 & 6.02 \\
\hline $6 f$ & & $\mathrm{C}_{2} \mathrm{H}_{5}$ & $\mathrm{D}$ & 9 & $c a .180$ & $278(7,200)$ & $3.12,3.38$ & 5.01 & 5.58 & 5.78 \\
\hline $6 \mathrm{~g}$ & & & $\mathbf{D}$ & 23 & ca. 195 & $\begin{array}{l}281(7,700) \\
287(7,600)\end{array}$ & $3.29,3.59$ & 5.07 & 5.62 & 5.83 \\
\hline 6h & & $\mathrm{CH}_{2} \mathrm{OCH}_{3}$ & $\mathrm{D}$ & 75 & ca. 160 & $279(9,400)$ & $3.24,3.57$ & 5.19 & 5.77 & 6.20 \\
\hline $6 i$ & & $\mathrm{CH}_{2} \mathrm{Ph}$ & $\mathrm{D}$ & 31 & ca. 175 & $280(8,900)$ & - & 5.07 & 5.74 & 6.20 \\
\hline $6 \mathbf{j}$ & & $\mathrm{CH}_{3}$ & $\mathbf{D}$ & 48 & $180 \sim 185$ & $280(10,500)$ & $3.25,3.57$ & 5.18 & 5.72 & 5.97 \\
\hline
\end{tabular}


Table 3. (Continued)

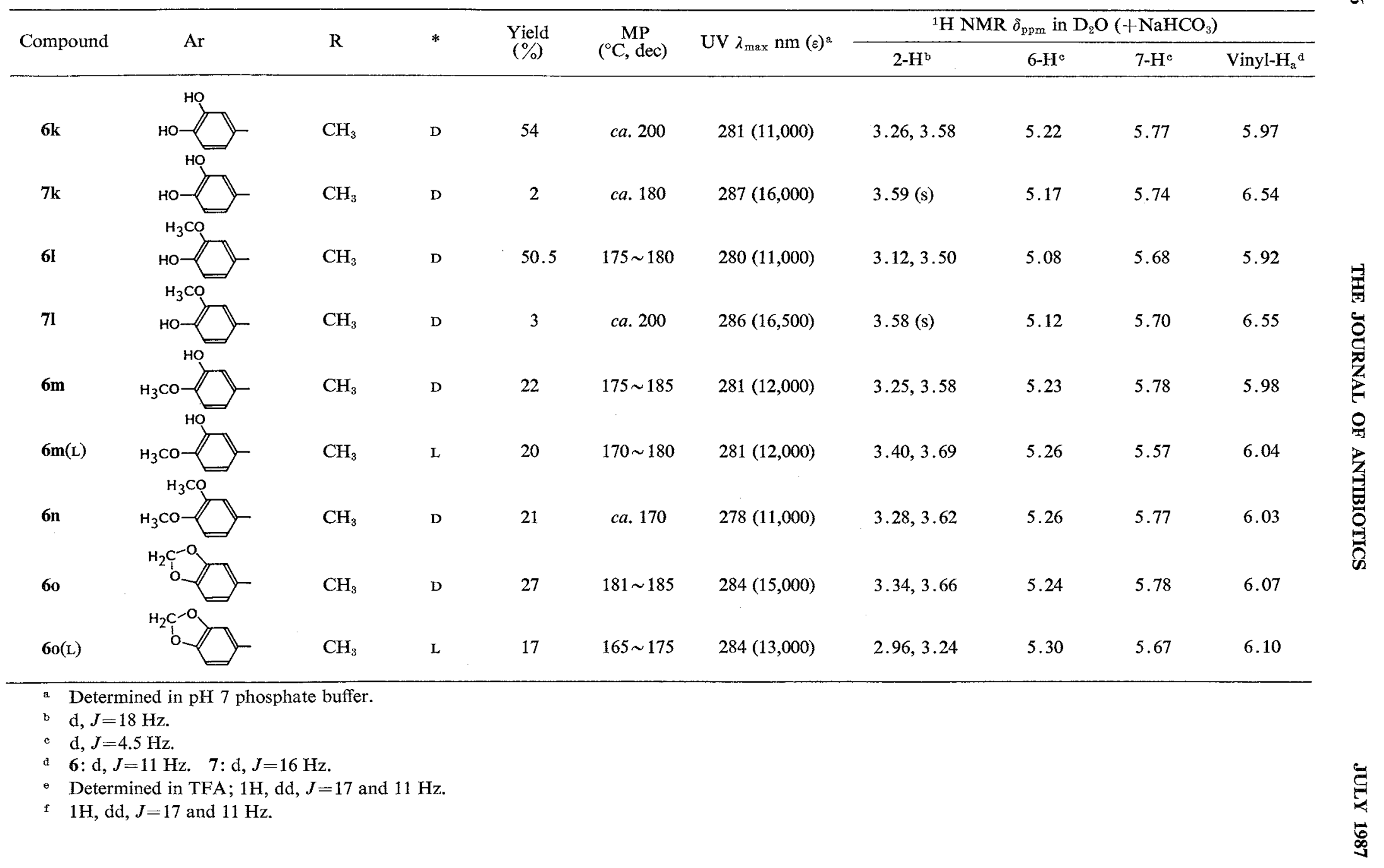


the 3-side chain which might be sterically close to the $2-\mathrm{H}$ protons.

\section{Antimicrobacterial Acitivity}

Minimum inhibitory concentrations (MICs) of cephalosporins in the present study were determined by 2 -fold serial agar dilution method in Mueller-Hinton agar against 15 test organisms, which consist of five strains each of penicillin-sensitive Staphylococcus aureus (designated GP-S group), penicillinaseproudcing $S$. aureus (GP-R group) and cephalothin-sensitive Gram-negative bacteria (GN group). The in vitro activity of the derivatives was primarily assessed by the geometric mean of MICs for each of the 3 groups of test organisms.

Table 4 shows the in vitro antibacterial activity of BMY-28100 (6d) and its analogs having a variety of alkenyl groups at the 3-side chain. Most of the 3-alkenylcephems in Table 4 were more active than cephalexin and cefaclor against both Gram-positive test organism groups, GP-S and GP-R, whereas they, except BMY-28100 and 6i, were between cephalexin and cefaclor in the activity against Gramnegative organisms (the GN group). BMY-28100 (6d) was significantly more acitive than cephalexin against all of the three groups of test organisms. As compared to cefaclor, BMY-28100 was more active against both GP-S and GP-R groups, and slightly more active against the GN group. Compounds $\mathbf{6 b}$ and $\mathbf{6 f}$, the lower and higher homologs of 6d, were comparable to $6 \mathbf{d}$ against both GP groups, but $3 \sim$ 4 times less active against the GN group. The phenylpropenyl derivative (6i) is the most active against both GP-S and GP-R groups, but almost inactive against the GN group.

Table 5 shows in vitro antibacterial activity of a variety of substituted phenyl derivatives in the 7side chain. All compounds except $6 \mathbf{k}$ were more active than cephalexin and cefaclor against GP-S and GP-R. Against the GN group, unsubstituted phenyl (6c) and 4-hydroxy-substituted phenyl derivatives $(6 \mathrm{~d}, 6 \mathrm{j}$ and $\mathbf{6 l}$, except $\mathbf{6 k}$ ) were as active as or more active than cefaclor. Only compound $6 \mathrm{k}$ was weakly active against all test organism groups.

Compounds having a 4-hydroxy substitution in the phenyl ring, $6 \mathrm{~d}, 6 \mathrm{j}, 6 \mathrm{k}$ and 61 , were examined

Table 4. In vitro activity of BMY-28100 and analogs (1), (Mueller-Hinton agar, $10^{6} \mathrm{cfu} / \mathrm{ml}, 37^{\circ} \mathrm{C}, 18$ hours).

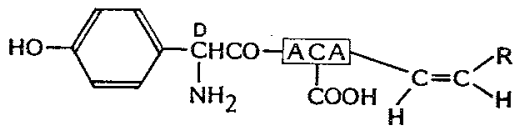

\begin{tabular}{|c|c|c|c|c|}
\hline \multirow{2}{*}{ Compound } & \multirow{2}{*}{$\mathrm{R}$} & \multicolumn{3}{|c|}{ Geometric mean of MIC $(\mu \mathrm{g} / \mathrm{ml})$} \\
\hline & & GP-S* & GP-R & GN \\
\hline $6 \mathrm{~b}$ & $\mathrm{H}$ & 0.40 & 1.2 & 3.1 \\
\hline $\begin{array}{c}\text { 6d } \\
(\mathrm{BMY}-28100)\end{array}$ & $\mathrm{CH}_{3}$ & 0.30 & 0.70 & 0.92 \\
\hline $6 f$ & $\mathrm{C}_{2} \mathrm{H}_{3}$ & 0.40 & 1.4 & 4.1 \\
\hline $6 \mathrm{~g}$ & . & 0.30 & 1.1 & 4.2 \\
\hline $6 \mathrm{~h}$ & $\mathrm{CH}_{2} \mathrm{OCH}_{3}$ & 0.70 & 2.1 & 3.1 \\
\hline $6 i$ & $\mathrm{CH}_{2} \mathrm{Ph}$ & 0.23 & 0.70 & $>50$ \\
\hline Cephalexin & & 1.2 & 4.1 & 5.8 \\
\hline Cefaclor & & 0.61 & 3.6 & 1.1 \\
\hline
\end{tabular}

* GP-S: Penicillin (PC)-sensitive Staphylococcus aureus (5 strains), GP-R: PC-resistant S. aureus (5), GN: Cephalothin-sensitive Escherichia coli (2), Klebsiella pneumoniae (1) and Proteus mirabilis (2). 
Table 5. In vitro activity of BMY-28100 and analogs (2), (Mueller-Hinton agar, $10^{\circ} \mathrm{cfu} / \mathrm{ml}, 37^{\circ} \mathrm{C}, 18$ hours).

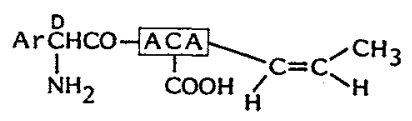

\begin{tabular}{|c|c|c|c|c|}
\hline \multirow{2}{*}{ Compound } & \multirow{2}{*}{$\mathrm{Ar}$} & \multicolumn{3}{|c|}{ Geometric mean of MIC $(\mu \mathrm{g} / \mathrm{ml})$} \\
\hline & & GP-S & GP-R & GN \\
\hline 6c & & 0.40 & 1.2 & 1.2 \\
\hline $\begin{array}{c}\text { 6d } \\
(\mathrm{BMY}-28100)\end{array}$ & & 0.30 & 0.70 & 0.92 \\
\hline $6 j$ & & 0.13 & 0.40 & 1.2 \\
\hline $6 \mathrm{k}$ & & 13 & 14 & 14 \\
\hline 61 & & 0.35 & 1.1 & 0.92 \\
\hline $6 \mathrm{~m}$ & & 0.35 & 1.1 & 2.1 \\
\hline $6 n$ & & 0.46 & 1.2 & 7.2 \\
\hline 60 & & 0.20 & 0.61 & 7.2 \\
\hline Cephalexin & & 1.2 & 4.1 & 5.8 \\
\hline Cefaclor & & 0.61 & 3.6 & 1.1 \\
\hline
\end{tabular}

Abbreviations: See footnote in Table 4.

Table 6. Effect of culture medium on in vitro activity of BMY-28100 and analogs.

\begin{tabular}{clccc}
\hline \multirow{2}{*}{ Compound } & Medium* & \multicolumn{3}{c}{ Geometric mean of MIC $(\mu \mathrm{g} / \mathrm{ml})$} \\
\cline { 2 - 5 } & & GP-S & GP-R & GN \\
\hline 6d & MHA & 0.30 & 0.70 & 0.92 \\
$($ BMY-28100) & NA & 0.20 & 0.40 & 0.80 \\
$\mathbf{6 j}$ & MHA & 0.13 & 0.40 & 1.2 \\
& NA & 0.11 & 0.26 & 0.80 \\
$6 \mathbf{6}$ & MHA & 13 & 14 & 14 \\
& NA & 0.92 & 1.4 & 2.1 \\
6 & MHA & 0.35 & 1.1 & 0.92 \\
& NA & 0.40 & 0.80 & 0.70 \\
Cephalexin & MHA & 1.2 & 4.1 & 5.8 \\
& NA & 0.7 & 1.8 & 5.5 \\
\hline
\end{tabular}

* MHA: Mueller-Hinton agar, NA: nutrient agar (incubation: $37^{\circ} \mathrm{C}, 18$ hours, $10^{\circ} \mathrm{cfu} / \mathrm{ml}$ ).

Abbreviations: See footnote in Table 4.

for their activity in Mueller-Hinton agar and nutrient agar. As shown in Table 6, 6k demonstrated much greater activity in nutrient agar than in Mueller-Hinton agar. The MICs of other compounds in this group did not show any significant difference between the two media tested. HPLC study 
Table 7. Effect of stereochemistry of the 3-propenyl group on in vitro activity of BMY-28100 and analogs, (Mueller-Hinton agar, $10^{\circ} \mathrm{cfu} / \mathrm{ml}, 37^{\circ} \mathrm{C}, 18$ hours).

\begin{tabular}{|c|c|c|c|c|c|}
\hline \multirow{2}{*}{ Compound } & \multirow{2}{*}{$\mathrm{Ar}$} & \multirow{2}{*}{$*$} & \multicolumn{3}{|c|}{ Geometric mean of MIC $(\mu \mathrm{g} / \mathrm{ml})$} \\
\hline & & & GP-S & GP-R & GN \\
\hline $\begin{array}{c}\text { 6d } \\
(\mathrm{BMY}-28100)\end{array}$ & & $Z$ & 0.30 & 0.70 & 0.92 \\
\hline $7 d$ & & $E$ & 0.36 & 1.4 & 6.3 \\
\hline 61 & & $Z$ & 0.35 & 1.1 & 0.92 \\
\hline 71 & & $E$ & 0.46 & 1.6 & 14 \\
\hline Cephalexin & & & 1.2 & 4.1 & 5.8 \\
\hline Cefaclor & & & 0.61 & 3.6 & 1.1 \\
\hline
\end{tabular}

Abbreviations: See footnote in Table 4.

Table 8. Effect of configuration of the phenylglycine moiety in the 7-side chain on in vitro activity of BMY-28100 and analogs, (Mueller-Hinton agar, $10^{6} \mathrm{cfu} / \mathrm{ml}, 37^{\circ} \mathrm{C}, 18$ hours).

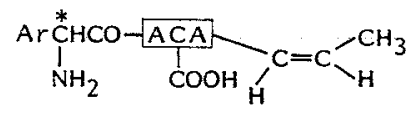

\begin{tabular}{|c|c|c|c|c|c|}
\hline \multirow{2}{*}{ Compound } & \multirow{2}{*}{$\mathrm{Ar}$} & \multirow{2}{*}{$*$} & \multicolumn{3}{|c|}{ Geometric mean of MIC $(\mu \mathrm{g} / \mathrm{ml})$} \\
\hline & & & GP-S & GP-R & GN \\
\hline $\begin{array}{c}\mathbf{6 d} \\
(\mathrm{BMY}-28100)\end{array}$ & & D & 0.30 & 0.70 & 0.92 \\
\hline $6 e$ & & $\mathbf{L}$ & 33 & $>50$ & $>50$ \\
\hline $6 m$ & & D & 0.35 & 1.1 & 2.1 \\
\hline $6 m(L)$ & & L & 4.2 & 12.5 & 29 \\
\hline 60 & & $\mathrm{D}$ & 0.20 & 0.61 & 7.2 \\
\hline $60(L)$ & & L & 3.1 & 9.5 & $>50$ \\
\hline Cephalexin & & & 1.2 & 4.1 & 5.8 \\
\hline Cefaclor & & & 0.61 & 3.6 & 1.1 \\
\hline
\end{tabular}

Abbreviations: See footnote in Table 4.

showed that $6 \mathrm{k}$ as well as $6 \mathrm{~d}$ were stable under the conditions of MIC determination (for 18 hours at $37^{\circ} \mathrm{C}$ ) in both Mueller-Hinton agar and nutrient agar. At this time, it is not found the reason why the MIC difference of $6 \mathrm{k}$ occurred in both media. 
Table 9. Mouse blood levels of BMY-28100 and analogs, (ddY-mice, $n=5)$.

\begin{tabular}{|c|c|c|c|c|c|c|}
\hline \multirow{3}{*}{ Compound } & \multicolumn{6}{|c|}{ Dose } \\
\hline & \multicolumn{3}{|c|}{$100 \mathrm{mg} / \mathrm{kg}$, po } & \multicolumn{3}{|c|}{$20 \mathrm{mg} / \mathrm{kg}$, im } \\
\hline & $\underset{(\mu \mathrm{g} / \mathrm{ml})}{\mathrm{Cmax}}$ & $\begin{array}{c}\mathrm{T}_{1 / 2} \\
\text { (hours) }\end{array}$ & $\begin{array}{c}\text { AUC } \\
(\mu \mathrm{g} \cdot \text { hours } / \mathrm{ml})\end{array}$ & $\underset{(\mu \mathrm{g} / \mathrm{ml})}{\operatorname{Cmax}}$ & $\begin{array}{c}\mathrm{T}_{1 / 2} \\
\text { (hours) }\end{array}$ & $\frac{\text { AUC }}{(\mu \mathrm{g} \cdot \text { hours } / \mathrm{ml})}$ \\
\hline $\mathbf{6 b}$ & 30 & 1.2 & 28 & 23 & 0.37 & 15 \\
\hline $6 c$ & 33 & 1.1 & 46 & 16 & 0.58 & 13 \\
\hline $\begin{array}{c}\text { 6d } \\
(\mathrm{BMY}-28100)\end{array}$ & 39 & 1.2 & 60 & 27 & 0.44 & 18 \\
\hline $6 \mathrm{f}$ & 36 & 1.9 & 85 & ND & ND & ND \\
\hline $6 j$ & 25 & 1.7 & 37 & 21 & 0.48 & 13 \\
\hline 61 & 31 & 1.6 & 50 & 21 & 0.46 & 14 \\
\hline $6 \mathrm{k}$ & 175 & 1.9 & 353 & 67 & 1.0 & 150 \\
\hline $6 \mathrm{~m}$ & 32 & 0.76 & 42 & 15 & 0.22 & 7.2 \\
\hline $6 n$ & 18 & 1.5 & 39 & 16 & 0.58 & 8.1 \\
\hline 60 & 21 & 0.87 & 32 & 9.2 & 0.48 & 5.4 \\
\hline Cephalexin & 47 & 1.4 & 57 & 26 & 0.44 & 16 \\
\hline Cefaclor & 32 & 1.3 & 42 & 21 & 0.45 & 13 \\
\hline
\end{tabular}

ND: Not determined.

Table 10. Mouse urinary recovery of BMY-28100 and analogs, (ddY-mice, $n=5)$.

\begin{tabular}{ccccccc}
\hline \multirow{2}{*}{ Compound } & \multicolumn{5}{c}{$\%$ Recovery (Dose: $100 \mathrm{mg} / \mathrm{kg}$, po) } \\
\cline { 2 - 6 } & $0 \sim 2$ (hours) & $2 \sim 4$ (hours) & $4 \sim 6$ (hours) & $6 \sim 24$ (hours) & Total \\
\hline 6d & 36 & 24 & 5.4 & 2.7 & 68 \\
(BMY-28100) & & & & 4.7 & 59 & 357 \\
61 & 26 & 23 & 5.2 & 35 & 63 \\
6k & 119 & 165 & 38 & 1.5 & 8.2 & \\
Cefaclor & 35 & 18 & & & & \\
\hline
\end{tabular}

Tables 7 and 8 show the structure-activity relationships on the stereochemistry of the 3- and 7-side chains, respectively. As shown in Table 7, the 3-cis-propenyl derivatives (6d and 61) were more active than the corresponding trans isomers (7d and $7 \mathbf{l})$, especially in the Gram-negative activity. Table 8 shows that the $\mathrm{L}$-phenylglycyl derivatives $(6 \mathrm{e}, 6 \mathrm{~m}(\mathrm{~L})$ and $60(\mathrm{~L}))$ were much less active than the $\mathrm{D}$-congeners (6d, $6 \mathrm{~m}$ and $\mathbf{6 0})$ as was the case in many $\beta$-lactam antibiotics ${ }^{2,10)}$.

Table 9 shows blood level parameters for mice treated orally and intramuscularly with the present series of cephalosporins. In general, they were well absorbed by oral administration. Exceptionally high Cmax (the maximum concentration in the blood achieved) and AUC (area under the drug concentration-time curve) values observed for $6 \mathrm{k}$ suggested that $6 \mathrm{k}$ might be metabolized to a more active substance in vivo. Table 10 shows the urinary recovery after oral administration of $6 \mathbf{d}, 6 \mathbf{l}$ and $6 \mathrm{k}$. Again the urinary recovery of $6 \mathbf{k}$ was found unrealistically high.

Chromatographic study revealed that the urine and serum samples of mice administered $6 \mathrm{k}$ by oral route contained a considerable amount of $6 \mathbf{l}$ along with $\mathbf{6 k}$ as shown in Fig. 2. This metabolism was also observed in rats and confirmed by isolation of 61 from the rat urine sample collected after oral administration of $6 \mathbf{k}$.

Table 11 shows the in vivo activity of cephalosporin derivatives against $S$. aureus Smith and Escherichia coli Juhl infections determined after oral and intramuscular administrations. Small differences between oral and intramuscular activities in most compounds of Table 11 indicated their good oral 
Fig. 2. Bioconversion of $6 \mathrm{k}$ to $6 \mathrm{I}$.<smiles>C/C=C\C1=C(C(=O)O)N2C(=O)C(NC(=O)C(N)c3ccc(O)c(O)c3)C2SC1</smiles><smiles>[Y]NC(=O)C(N)c1ccc(O)c(C2CC2)c1</smiles>

61 6k

Paper chromatography : Butanol - ethanol - water $(4: 1: 5)$ Bioautography: Micrococcus luteus PCI-1001

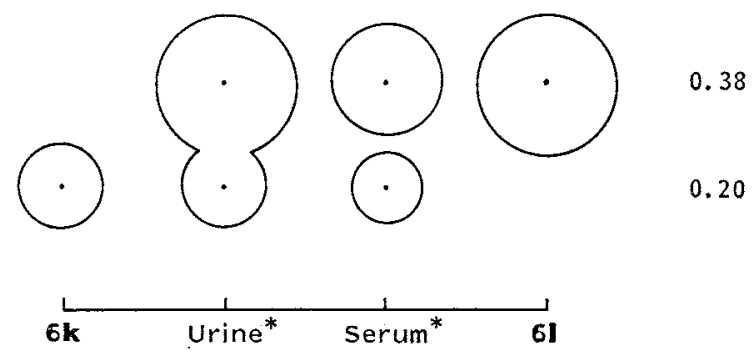

* Collected after oral administration of compound $6 \mathbf{k}$ to mice

Table 11. In vivo activity of BMY-28100 and analogs, (ddY-mice, $n=5)$.

\begin{tabular}{|c|c|c|c|c|}
\hline \multirow{3}{*}{ Compound } & \multicolumn{4}{|c|}{$\mathrm{PD}_{50}(\mathrm{mg} / \mathrm{kg})$} \\
\hline & \multicolumn{2}{|c|}{ Staphylococcus aureus Smith } & \multicolumn{2}{|c|}{ Escherichia coli Juhl } \\
\hline & po & $\operatorname{im}$ & po & $\operatorname{im}$ \\
\hline $6 b$ & 0.30 & $\mathrm{ND}$ & 6.3 & $\mathrm{ND}$ \\
\hline $6 c$ & 0.18 & 0.15 & 1.5 & 0.89 \\
\hline $6 d$ & 0.12 & 0.10 & 0.69 & 0.51 \\
\hline \multicolumn{5}{|l|}{ (BMY-28100) } \\
\hline $7 d$ & 0.20 & 0.13 & 7.5 & 6.0 \\
\hline $6 f$ & 0.58 & ND & 5.5 & ND \\
\hline $6 \mathbf{j}$ & 0.17 & 0.11 & 3.0 & 1.7 \\
\hline $6 \mathrm{k}$ & 0.12 & 0.12 & 0.56 & 0.48 \\
\hline 61 & 0.12 & 0.10 & 0.65 & 0.65 \\
\hline $6 \mathrm{~m}$ & 0.12 & 0.12 & 4.1 & 1.9 \\
\hline $6 n$ & 0.23 & 0.31 & 16 & 9.0 \\
\hline 60 & 0.18 & 0.18 & 9.0 & 4.7 \\
\hline Cephalexin & 0.31 & 0.24 & 9.1 & 6.3 \\
\hline Cefaclor & 0.24 & 0.37 & 0.63 & 1.1 \\
\hline
\end{tabular}

ND: Not determined.

absorbability. The 3-vinyl (6b) and 3-butenyl (6f) derivatives were much less effective against both infections than the 3-propenyl derivative (6d). The trans propenyl derivative (7d) was somewhat less effective than the cis isomer (6d) against $S$. aureus Smith and more than 10 times less effective against $E$. coli Juhl when administered orally and intramuscularly. The phenyl (6c) and 3-chloro-4-hydroxyphenyl (6j) analogs of $6 \mathbf{d}$ were as effective as $6 \mathbf{d}$ against the $S$. aureus infection, but $2 \sim 4$ times less active than $6 \mathrm{~d}$ against $E$. coli $\mathrm{Juhl}$. The 3,4-dihydroxyphenyl (6k) and 4-hydroxy-3-methoxyphenyl (61) analogs 
were as active as $\mathbf{6 d}$ against both infections. Better in vivo activity of $\mathbf{6 k}$ than that expected from its MIC value, would be due to the bioconversion of $\mathbf{6 k}$ to $\mathbf{6 1}$ described above.

BMY-28100 (6d) was selected as a lead compound in this series for further evaluation ${ }^{11)}$.

\section{Experimental}

Melting points were determined with a Yanagimoto micro hot-stage apparatus and are uncorrected. IR spectra were recorded on Jasco IRA-1 and UV spectra on Shimadzu UV-200 spectrophotometer. NMR spectra were recorded on a Jeol CL-60HL or on a Varian FT-80A spectrometer.

3-Triphenylphosphoniomethyl Derivatives, 4 (Table 1): General Procedure Illustrated with the Preparation of Diphenylmethyl 7-[D- $\alpha$-(N-tert-butoxycarbonylamino)- $\alpha$-(4-hydroxyphenyl)acetamido]3-(triphenylphosphonio)methyl-3-cephem-4-carboxylate Iodide (4b)

To a stirred solution of $107.8 \mathrm{~g}(0.26 \mathrm{~mol})$ of diphenylmethyl 7-amino-3-chloromethyl-3-cephem4-carboxylate $(1)^{9)}$ and $83.3 \mathrm{~g}(0.312 \mathrm{~mol})$ of $\mathrm{D}-\alpha$-( $N$-tert-butoxycarbonylamino)- $\alpha$-(4-hydroxyphenyl)acetic acid in $1,200 \mathrm{ml}$ of dry THF was added $56 \mathrm{~g}(0.273 \mathrm{~mol})$ of $N, N^{\prime}$-dicyclohexylcarbodiimide (DCC) at $5 \sim 10^{\circ} \mathrm{C}$. The mixture was stirred at room temp for 1.5 hours and concentrated to $300 \mathrm{ml}$. The concentrate was diluted with 1 liter of EtOAc to separate dicyclohexylurea, which was removed by filtration. The filtrate was washed successively with aq $\mathrm{NaHCO}_{3}, \mathrm{H}_{2} \mathrm{O}$ and a satd $\mathrm{NaCl}$ solution, dried over anhydrous magnesium sulfate and evaporated to dryness to give diphenylmethyl $7-[\alpha-(N-$ tertbutoxycarbonylamino)- $\alpha$-(4-hydroxyphenyl)acetamidol-3-chloromethyl-3-cephem-4-carboxylate (3b) as a foamy solid, which was used without further purification.

To a solution of $3 \mathrm{~b}$ in 1 liter of acetone was added $195 \mathrm{~g}(1.3 \mathrm{~mol})$ of $\mathrm{NaI}$ and the mixutre was stirred at room temp for 30 minutes and evaporated to dryness. The residue was dissolved with 2 liters of EtOAc and the solution was washed with aq $\mathrm{Na}_{2} \mathrm{~S}_{2} \mathrm{O}_{3}, \mathrm{H}_{2} \mathrm{O}$ and a satd $\mathrm{NaCl}$ solution and dried over anhydrous magnesium sulfate. The solution was concentrated to 1 liter and the concentrate was cooled to $5^{\circ} \mathrm{C}$ and mixed with $88.6 \mathrm{~g}(0.338 \mathrm{~mol})$ of triphenylphosphine under stirring. The mixture was stirred at room temp for 16 hours to separate $4 \mathrm{~b}$, which was collected by filtration, washed with cold EtOAc and ether, and dried in vacuo over $\mathrm{P}_{2} \mathrm{O}_{5}$. Yield $232 \mathrm{~g}(88 \%)$ : MP $170 \sim 180^{\circ} \mathrm{C}(\mathrm{dec})$; IR $\nu_{\mathrm{max}}^{\mathrm{KBr}} \mathrm{cm}^{-1} 1780$, $1670,1490,1420,1350,1240,1150,1090 ; \mathrm{UV} \lambda_{\mathrm{max}}^{\mathrm{MeOH}} \mathrm{nm}(\varepsilon) 269(10,600), 277(10,000) ;{ }^{1} \mathrm{H} \mathrm{NMR}(60 \mathrm{MHz}$, DMSO- $\left.d_{6}\right) \delta 1.42\left(9 \mathrm{H}, \mathrm{s}, \mathrm{C}\left(\mathrm{CH}_{3}\right)_{3}\right), 3.45(2 \mathrm{H}, \mathrm{br} \mathrm{s}, 2-\mathrm{H}), 5.0 \sim 5.4\left(3 \mathrm{H}, \mathrm{m}, \mathrm{CH}_{2} \mathrm{P}\right.$ and $\left.6-\mathrm{H}\right), 5.7(1 \mathrm{H}, \mathrm{m}$, 7-H), $6.63(2 \mathrm{H}, \mathrm{d}, J=9 \mathrm{~Hz}$, phenyl-H), $7.1 \sim 7.45(12 \mathrm{H}, \mathrm{m}$, phenyl-H), $7.5 \sim 7.9(15 \mathrm{H}, \mathrm{m}$, phenyl-H).

Anal Calcd for $\mathrm{C}_{52} \mathrm{H}_{49} \mathrm{~N}_{3} \mathrm{O}_{7} \mathrm{SPI}$ : C 61.36, H 4.85, N 4.13, S 3.15.

Found:

C $61.26, \mathrm{H} 4.82, \mathrm{~N} 4.11, \mathrm{~S} 3.92$.

The Wittig Reaction Products, 5 (Table 2): General Procedure Illustrated with the Preparation of Diphenylmethyl 7-[D- $\alpha$-( $N$-tert-butoxycarbonylamino)- $\alpha$-(4-hydroxyphenyl)acetamido]-3-(1-propenyl)-3cephem-4-carboxylate (5d)

To a solution of $101.7 \mathrm{~g}(0.1 \mathrm{~mol})$ of $4 \mathrm{~b}$ in 2 liters of $\mathrm{CHCl}_{3}$ was added a mixture of 1 liter of $\mathrm{H}_{2} \mathrm{O}$ and $110 \mathrm{ml}(0.11 \mathrm{~mol})$ of $1 \mathrm{~N} \mathrm{NaOH}$ and the mixture was shaken for 5 minutes. The organic layer was separated, washed with $\mathrm{H}_{2} \mathrm{O}$ and subsequently with aq $\mathrm{NaCl}$, and dried over anhydrous magnesium sulfate. The dried organic solution was filtered and concentrated to $500 \mathrm{ml}$ under reduced pressure. The concentrate was cooled and mixed with $200 \mathrm{ml}$ of $90 \%$ acetaldehyde under stirring. The mixture was stirred at room temp for 30 minutes and dried over anhydrous magnesium sulfate. The filtrate was chromatographed on a Silica gel column (Wako-gel C-200, $1 \mathrm{~kg}$ ) by eluting with $\mathrm{CHCl}_{3}$ and $\mathrm{CHCl}_{3}$ $\mathrm{MeOH}(99: 1)$. The desired fractions were collected and evaporated to dryness. Since the residue still contained a small amount of triphenylphosphine oxide, it was re-chromatographed on a Silica gel column (Kieselgel 60,300 g) by eluting with toluene - EtOAc $(4: 1)$. The eluate was monitored with TLC (silica gel, 50\% toluene-EtOAc). The desired fractions were combined and evaporated to dryness. The oily residue was triturated with ether - isopropyl ether $-n$-hexane to give $20.5 \mathrm{~g}(31 \%)$ of $\mathbf{5 d}$ melting at $120 \sim 130^{\circ} \mathrm{C}(\mathrm{dec}): \mathrm{IR} \nu_{\mathrm{max}}^{\mathrm{KBr}} \mathrm{cm}^{-1} 1780,1710 \sim 1670,1490,1360,1210,1150$; UV $\lambda_{\mathrm{max}}^{\mathrm{MeOH}} \mathrm{nm}(\varepsilon)$ $283(8,300) ;{ }^{1} \mathrm{H} \mathrm{NMR}\left(\mathrm{CDCl}_{3}\right) \delta 1.3 \sim 1.5\left(12 \mathrm{H}, \mathrm{m}, \mathrm{C}\left(\mathrm{CH}_{3}\right)_{3}\right.$ and $\left.\mathrm{C}=\mathrm{CCH}_{3}\right), 3.22(2 \mathrm{H}$, br s, $2-\mathrm{H}), 4.90$ $(1 \mathrm{H}, \mathrm{d}, J=4.5 \mathrm{~Hz}, 6-\mathrm{H}), 5.15(1 \mathrm{H}, \mathrm{s}, \mathrm{CHCO}), 5.5 \sim 5.9\left(2 \mathrm{H}, \mathrm{m}, \mathrm{CH}=\mathrm{CHCH}_{3}\right.$ and $\left.7-\mathrm{H}\right), 6.07(1 \mathrm{H}, \mathrm{d}$, 
$\left.J=11 \mathrm{~Hz}, \mathrm{CH}=\mathrm{CHCH}_{3}\right), 6.63(2 \mathrm{H}, \mathrm{d}, J=9 \mathrm{~Hz}$, phenyl-H), $6.91(1 \mathrm{H}, \mathrm{s}, \mathrm{C} H$-(phenyl) $), 7.09(2 \mathrm{H}, \mathrm{d}$, $J=9 \mathrm{~Hz}$, phenyl-H), $7.2 \sim 7.5(10 \mathrm{H}, \mathrm{m}$, phenyl-H).

Anal Calcd for $\mathrm{C}_{38} \mathrm{H}_{37} \mathrm{~N}_{2} \mathrm{O}_{7} \mathrm{~S} \cdot \frac{1}{2} \mathrm{H}_{2} \mathrm{O}$ : C 65.04, $\mathrm{H} 5.76, \mathrm{~N} 6.32, \mathrm{~S} 4.82$. Found:

C 65.10, H 5.73, N 6.13, S 5.23.

\section{3-Alkenyl-7-arylglycylaminocephalosporins, 6 and 7 (Table 3)}

General procedure accompanied with separation of the $Z$ isomer (6) and the $E$ isomer (7) regarding the 3-alkenyl side chain is illustrated by the preparation of $\mathbf{6 d}$ and $\mathbf{7 d}$, and that accompanied with separation of the $\mathrm{D}$ isomer and $\mathrm{L}$ isomer regarding the 7-arylglycyl moiety by the preparation of $6 \mathbf{d}$ and $6 \mathrm{e}$ as shown below.

7-[D- $\alpha$-Amino- $\alpha$-(4-hydroxyphenyl)acetamido]-3-[(Z)-1-propenyl]-3-cephem-4-carboxylic Acid (6d, BMY-28100) and Its $E$ Isomer (7d)

A mixture of $20 \mathrm{~g}(0.03 \mathrm{~mol})$ of $5 \mathrm{~d}$ and $60 \mathrm{ml}$ of TFA was stirred at room temp for 30 minutes and then diluted with $500 \mathrm{ml}$ of ether and $500 \mathrm{ml}$ of isopropyl ether. The precipitate separated was collected by filtration and washed with ether. To a solution of the precipitate in $50 \mathrm{ml}$ of $\mathrm{MeOH}$ was added $90 \mathrm{ml}$ of $1 \mathrm{M}$ solution of sodium 2-ethylhexanoate (SEH) in EtOAc to afford a precipitate, which was collected by filtration, washed with EtOAc and ether, and dried in vacuo over $\mathrm{P}_{2} \mathrm{O}_{5}$ to give $11.9 \mathrm{~g}$ of crude 6d containing some amount of 7d. The crude 6d was dissolved in $50 \mathrm{ml}$ of $0.01 \mathrm{M}$ phosphate buffer (pH 7.2) - methanol solution (85:15) and the solution was adjusted to $\mathrm{pH} 6$ with $6 \mathrm{~N} \mathrm{HCl}$ and chromatographed on a preparative HPLC (prepPAK-500/C 18 , System 500 , Waters). The column was eluted with phosphate buffer solution $(0.01 \mathrm{M}, \mathrm{pH} 7.2)$ containing $15 \% \mathrm{MeOH}$ and the eluate was monitored by analytical HPLC. The major component of the first 4 liters fraction was $6 \mathbf{d}$ and that of the second 1 liter fraction was 7d. The first fraction was concentrated to 2 liters. The concentrate was adjusted to $\mathrm{pH} 3$ with dilute $\mathrm{HCl}$ and the solution was charged on a column containing Diaion HP-20 (1 liter). The column was washed with 6 liters of $\mathrm{H}_{2} \mathrm{O}$ until the $\mathrm{pH}$ of the wash became 7 and then eluted with 4 liters of $30 \%$ aq $\mathrm{MeOH}$. The eluate was monitored by HPLC and the desired fraction ( $c a .2 .5$ liters) was concentrated to $50 \mathrm{ml}$ below $40^{\circ} \mathrm{C}$ under reduced pressure, during which time crystalline precipitate separated out. The concentrate was kept to stand at $0^{\circ} \mathrm{C}$ for 2 hours and the precipitated crystals were collected by filtration, washed with $80 \%$ aq acetone and then with acetone and dried in vacuo over $\mathrm{P}_{2} \mathrm{O}_{5}$ to give $4.09 \mathrm{~g}$ of $6 \mathrm{~d}$ melting at $218 \sim 220^{\circ} \mathrm{C}$ (dec). The mother liquor was concentrated to $10 \mathrm{ml}$, treated with $20 \mathrm{ml}$ of acetone and allowed to stand overnight in a refrigerator to afford crystalline precipitate, which was collected by filtration and dried in vacuo over $\mathrm{P}_{2} \mathrm{O}_{5}$ to give $670 \mathrm{mg}$ of the second crop of $6 \mathbf{6}$ as prisms. The total yield of $6 \mathrm{~d}$ was $4.76 \mathrm{~g}(40 \%)$ : IR $\nu_{\max }^{\mathrm{KB}} \mathrm{cm}^{-1} 1750,1680,1560,1520,1460,1390$, $1350,1270,1235$; UV $\lambda_{\max }$ (pH 7 phosphate buffer) nm $(\varepsilon) 228(12,300), 279(9,800) ;{ }^{1} \mathrm{H}$ NMR $\left(\mathrm{D}_{2} \mathrm{O}+\right.$ $\left.\mathrm{NaHCO}_{3}\right) \delta 1.71\left(3 \mathrm{H}, \mathrm{d}, J=6 \mathrm{~Hz}, \mathrm{CCH}_{3}\right), 3.27(1 \mathrm{H}, \mathrm{d}, J=18 \mathrm{~Hz}, 2-\mathrm{H}), 3.59(1 \mathrm{H}, \mathrm{d}, J=18 \mathrm{~Hz}, 2-\mathrm{H})$, $5.18(1 \mathrm{H}, \mathrm{d}, J=4.5 \mathrm{~Hz}, 6-\mathrm{H}), 5.22(1 \mathrm{H}, \mathrm{s}, \mathrm{CHCO}), 5.73(1 \mathrm{H}, \mathrm{d}, J=4.5 \mathrm{~Hz}, 7-\mathrm{H}), 5.5 \sim 6.0(1 \mathrm{H}, \mathrm{m}$, vinyl- $\left.\mathrm{H}_{\mathrm{b}}\right), 6.02\left(1 \mathrm{H}, \mathrm{d}, J=11 \mathrm{~Hz}\right.$, vinyl- $\left.\mathrm{H}_{\mathrm{a}}\right), 6.98(2 \mathrm{H}, \mathrm{d}, J=9 \mathrm{~Hz}$, phenyl- $\mathrm{H}), 7.41(2 \mathrm{H}, \mathrm{d}, J=9 \mathrm{~Hz}$, phenyl-H).

Anal Calcd for $\mathrm{C}_{18} \mathrm{H}_{19} \mathrm{~N}_{3} \mathrm{O}_{5} \mathrm{~S} \cdot \frac{1}{2} \mathrm{H}_{2} \mathrm{O}$ :

Found:

C 54.26, H 5.06, N 10.55 , S 8.05 .

C 54.17, H 5.11, N 10.36, S 8.21.

The second fraction from the preparative HPLC was concentrated to $500 \mathrm{ml}$. The concentrate was adjusted to $\mathrm{pH} 3$ with dilute $\mathrm{HCl}$ and chromatographed on an Diaion HP-20 column $(100 \mathrm{ml})$ by eluting with 1 liter each of $\mathrm{H}_{2} \mathrm{O}$ and $30 \% \mathrm{MeOH}$. The latter eluate (about $300 \mathrm{ml}$ ) was concentrated to $10 \mathrm{ml}$ and lyophilized to give $290 \mathrm{mg}$ of the crude trans isomer $7 \mathrm{~d}(55 \%$ pure). This material was dissolved in $100 \mathrm{ml}$ of $50 \% \mathrm{MeOH}$ and treated with activated carbon. The filtrate was concentrated to a volume of $20 \mathrm{ml}$ and allowed to stand overnight at $5^{\circ} \mathrm{C}$. Compound $7 \mathrm{~d}$ crystallized as colorless prisms which were collected by filtration and dried in vacuo. Yield $290 \mathrm{mg}(2 \%): \mathrm{MP} 230^{\circ} \mathrm{C}(\mathrm{dec}) ; \mathrm{IR} \nu_{\mathrm{max}}^{\mathrm{KBr}}$ $\mathrm{cm}^{-1} 1760,1680,1590,1550,1520,1450,1390,1350,1240$; UV $\lambda_{\max }$ (pH 7 phosphate buffer) $\mathrm{nm}(\varepsilon) 228$ (13,000), $292(16,900) ;{ }^{1} \mathrm{H}$ NMR $\left(60 \mathrm{MHz}, \mathrm{D}_{2} \mathrm{O}+\mathrm{Na}_{2} \mathrm{CO}_{3}\right) \delta 1.89\left(3 \mathrm{H}, \mathrm{d}, J=6 \mathrm{~Hz}, \mathrm{C}=\mathrm{CCH}_{3}\right), 3.60$ $(2 \mathrm{H}, \mathrm{s}, 2-\mathrm{H}), 5.13(1 \mathrm{H}, \mathrm{d}, J=4.5 \mathrm{~Hz}, 6-\mathrm{H}), 5.20(1 \mathrm{H}, \mathrm{s}, \mathrm{CHCO}), 5.68(1 \mathrm{H}, \mathrm{d}, J=4.5 \mathrm{~Hz}, 7-\mathrm{H}), 5.99$ $\left(1 \mathrm{H}, \mathrm{dq}, J=16\right.$ and $6 \mathrm{~Hz}$, vinyl- $\left.\mathrm{H}_{\mathrm{b}}\right), 6.54\left(1 \mathrm{H}, \mathrm{d}, J=16 \mathrm{~Hz}\right.$, vinyl- $\left.\mathrm{H}_{\mathrm{a}}\right), 6.98(2 \mathrm{H}, \mathrm{d}, J=9 \mathrm{~Hz}$, phenyl-H), $7.41(2 \mathrm{H}, \mathrm{d}, J=9 \mathrm{~Hz}$, phenyl-H). 
7-[D- and L- $\alpha$-Amino- $\alpha-(4-$ hydroxyphenyl)acetamido]-3-[(Z)-1-propenyl]-3-cephem-4-carboxylic Acids (6d and 6e)

A mixture of $5 \mathrm{~g}$ (7.62 mmol) of $5 \mathrm{e}$ and $20 \mathrm{ml}$ of TFA was stirred at room temp for 30 minutes and the mixture was diluted with $100 \mathrm{ml}$ of ether and $100 \mathrm{ml}$ of isopropyl ether. The precipitate separated was collected by filtration. To the solution of the precipitate in $20 \mathrm{ml}$ of $\mathrm{MeOH}$ was added $23 \mathrm{ml}$ ( $23 \mathrm{mmol}$ ) of $1 \mathrm{M}$ solution of SEH in EtOAc and the mixture was diluted with $300 \mathrm{ml}$ of EtOAc to afford the precipitate, which was collected by filtration, washed with ether and dried in vacuo over $\mathrm{P}_{2} \mathrm{O}_{5}$ to give $2.88 \mathrm{~g}$ of crude Na salt of a mixture of $6 \mathrm{~d}, 6 \mathrm{e}$.

The above experiment was repeated and the combined crude $\mathrm{Na}$ salt $(5 \mathrm{~g})$ was dissolved in $50 \mathrm{ml}$ of $\mathrm{MeOH}$, and the solution was acidified with $10 \mathrm{ml}$ of $1 \mathrm{~N} \mathrm{HCl}$ and chromatographed on a reverse-phase column packed with $400 \mathrm{ml}$ of the packing of prepPAK- $\mathrm{C}_{18}$ cartridge (Waters). The column was washed with $\mathrm{H}_{2} \mathrm{O}$ and eluted with $10 \% \mathrm{MeOH}$. The eluate was collected under monitoring with HPLC $(25 \% \mathrm{MeOH}-\mathrm{pH} 7$ phosphate buffer). At first the eluate contained $6 \mathrm{e}$ predominantly, then the content of $6 \mathrm{~d}$ increased to give $6 \mathrm{~d}$-rich fractions and finally $6 \mathrm{e}$ became a major component again. The 6e-rich fractions (the first and third parts of the above eluate) were combined and concentrated to $300 \mathrm{ml}$. The concentrate was re-chromatographed on a column with the same packing by eluting with $\mathrm{H}_{2} \mathrm{O}$ and $10 \% \mathrm{MeOH}$. The heart-cut fractions containing $6 \mathrm{e}$ of $10 \% \mathrm{MeOH}$ eluate were collected and concentrated to $10 \mathrm{ml}$ and cooled. The resulting crystalline solid was collected by filtration, washed with cold water and acetone and dried in vacuo over $\mathbf{P}_{2} \mathrm{O}_{5}$ to give $250 \mathrm{mg}$ of $6 \mathrm{e}$. The mother liquor and the side fractions containing $6 \mathrm{e}$ were combined and the mixture was again chromatographed similarly to afford $113 \mathrm{mg}$ of a second crop of $6 \mathrm{e}$. The total yield of $6 \mathrm{e}$ was $363 \mathrm{mg}(9 \%): \mathrm{MP} 200^{\circ} \mathrm{C}(\mathrm{dec}) ; \mathrm{IR} \nu_{\mathrm{max}}^{\mathrm{KBr}} \mathrm{cm}^{-1}$ $1760,1690,1590,1520,1400,1360,1270$; UV $\lambda_{\max }$ (pH 7 phosphate buffer) $\mathrm{nm}(\varepsilon) 229(13,000), 279$ $(9,900) ;{ }^{1} \mathrm{H}$ NMR $\left(60 \mathrm{MHz}, \mathrm{D}_{2} \mathrm{O}+\mathrm{Na}_{2} \mathrm{CO}_{3}\right) \delta 1.71\left(3 \mathrm{H}, \mathrm{d}, J=6 \mathrm{~Hz},=\mathrm{CHCH}_{3}\right), 3.36(1 \mathrm{H}, \mathrm{d}, J=18 \mathrm{~Hz}$, 2-H), $3.67(1 \mathrm{H}, \mathrm{d}, J=18 \mathrm{~Hz}, 2-\mathrm{H}), 4.68(1 \mathrm{H}, \mathrm{s}, \mathrm{CHCO}), 5.21(1 \mathrm{H}, \mathrm{d}, J=4.5 \mathrm{~Hz}, 6-\mathrm{H}), 5.59(1 \mathrm{H}, \mathrm{d}, J=$ $4.5 \mathrm{~Hz}, 7-\mathrm{H}), 5.5 \sim 6.0\left(1 \mathrm{H}, \mathrm{m}\right.$, vinyl- $\left.\mathrm{H}_{\mathrm{b}}\right), 6.02\left(1 \mathrm{H}, \mathrm{d}, J=11 \mathrm{~Hz}\right.$, vinyl- $\left.\mathrm{H}_{\mathrm{a}}\right), 6.96(2 \mathrm{H}, \mathrm{d}, J=9 \mathrm{~Hz}$, phenylH), $7.39(2 \mathrm{H}, \mathrm{d}, J=9 \mathrm{~Hz}$, phenyl-H).

Similarly, 6d-rich fractions (the second part of the eluate) were re-chromatographed by eluting with $10 \% \mathrm{MeOH}$. The desired fractions containing $6 \mathrm{~d}$ were collected and concentrated to $10 \mathrm{ml}$ and cooled in a refrigerator. The resulting crystalline solid was collected by filtration to give $1 \mathrm{~g}(25 \%)$ of $6 \mathrm{~d}$, which was identical with the product obtained from $\mathbf{5 d}$.

\section{Isolation of 61 from the Urine of Rats Fed $6 \mathbf{k}$}

Six male Wistar rats $(400 \sim 600 \mathrm{~g})$ were placed in steel metabolic cages after the oral administration of $6 \mathbf{k}$ at the dose of $100 \mathrm{mg} / \mathrm{kg}$ and urine was collected over a period of 24 hours. The rats were fed their regular diet and given water during the experiment.

The urine $(c a .90 \mathrm{ml})$ was adjusted to $\mathrm{pH} 3$ with $1 \mathrm{~N} \mathrm{HCl}$ and filtered to remove a precipitate. The filtrate was chromatographed on a column packed with $300 \mathrm{ml}$ of Diaion HP-20 by eluting with 2 liters of $\mathrm{H}_{2} \mathrm{O}$ and 2 liters of $30 \% \mathrm{MeOH}$ under monitoring with HPLC. The fractions containing the bioactive components of the $30 \% \mathrm{MeOH}$ eluate were collected, concentrated to $10 \mathrm{ml}$ and lyophilized to give $390 \mathrm{mg}$ of brown solid. A solution of the solid in $20 \mathrm{ml}$ of $\mathrm{H}_{2} \mathrm{O}$ was chromatographed on a column packed with $200 \mathrm{ml}$ of the packing of a prepPAK- $\mathrm{C}_{18}$ cartridge (Waters) by eluting with $\mathrm{H}_{2} \mathrm{O}, 5 \% \mathrm{MeOH}$, and $10 \% \mathrm{MeOH}$, successively. The first half of the $5 \% \mathrm{MeOH}$ eluate was concentrated to $5 \mathrm{ml}$ and lyophilized to give $44 \mathrm{mg}$ of $\mathbf{6 k}$ ( $70 \%$ pure) containing impurities derived from urine. The second half of the $5 \% \mathrm{MeOH}$ eluate was concentrated to $5 \mathrm{ml}$ and lyophilized to give $36 \mathrm{mg}$ of product, which was a mixture of $6 \mathbf{k}, 6 \mathbf{l}$ and impurities derived from urine. The eluate with $10 \% \mathrm{MeOH}(\mathrm{ca} .600 \mathrm{ml})$ was concentrated to $5 \mathrm{ml}$ and lyophilized to give $38 \mathrm{mg}$ of 61 (70\% pure by HPLC), which was re-chromatographed on a column of the same packing as above $(40 \mathrm{ml})$ by eluting with $\mathrm{H}_{2} \mathrm{O}, 5 \% \mathrm{MeOH}$ and $10 \% \mathrm{MeOH}$. The desired fractions eluted with $10 \% \mathrm{MeOH}$ were combined and concentrated to $5 \mathrm{ml}$ and lyophilized to give $16 \mathrm{mg}$ of powder which was identical with 61 by comparison of IR, UV, ${ }^{1} \mathrm{H}$ NMR and HPLC.

\section{Determinaton of MICs}

MICs were determined on solid medium by the standard 2-fold agar dilution method in Mueller- 
Hinton agar (Difco) or in nutrient agar (Eiken) after incubation at $37^{\circ} \mathrm{C}$ for 18 hours with an inoculum size of $10^{6} \mathrm{cfu} / \mathrm{ml}$.

\section{Blood Level and Urinary Recovery in Mice}

Five male $d d \mathrm{Y}$-mice, weighing 18 to $22 \mathrm{~g}$, were given an antibiotic solution by oral or intramuscular administration. Blood samples were collected from the orbital sinuses at $0.5,1,2,3,4,5,6$ and 7 hours after oral administration or at 10,20,30,40,50,60, 90 and 120 minutes after intramuscular administration and assayed by the paper disc-agar diffusion method using Micrococcus luteus PCI-1001 as an assay organism. The half life $\left(\mathrm{T}_{1 / 2}\right.$, hours) and area under the drug concentration-time curve (AUC, $\mu \mathrm{g} \cdot$ hours/ $\mathrm{ml}$ ) were calculated by the method of LEITNER et al ${ }^{122}$. Urine specimens were collected in four fractions ( 0 to 2,2 to 4,4 to 6 and 6 to 24 hours) after administration and assayed by the procedure same as that in the blood level experiment.

\section{Protective Effect}

Organisms were cultured overnight at $37^{\circ} \mathrm{C}$ in brain heart infusion broth and suspended in $5 \%$ hog mucin (American Laboratory, Omaha, Neb.). Male $d d \mathrm{Y}$-mice were infected intraperitoneally with about 100 times of the median lethal dose of the pathogen. Five mice at each dose level were individually given an antibiotic solution orally or intramuscularly just before the bacterial challenge. The $50 \%$ protective dose $\left(\mathrm{PD}_{50}, \mathrm{mg} / \mathrm{kg}\right)$ was calculated by the method of LITCHFIELD and WILCOXON ${ }^{13)}$, from survival rate recorded on 7 days after the bacterial infection.

\section{References}

1) WICK, W. E. \& W. S. BONIECE: In vitro and in vivo laboratory evaluation of cephaloglycin and cephaloridine. Appl. Microbiol. 13: 248 253, 1965

2) Spencer, J. L.; E. H. FlynN, R. W. Roeske, F. Y. Siu \& R. R. Chauvette: Chemistry of cephalosporin antibiotics. VII. Synthesis of cephaloglycin and some homologs. J. Med. Chem. 9: 746 750, 1966

3) Ryan, C. W.; R. L. Stmon \& E. M. Van Heyningen: Chemistry of cephalosporin antibiotics. XIII. Desacetoxycephalosporins. The synthesis of cephalexin and some analogs. J. Med. Chem. 12: 310 313,1969

4) Dolfini, J. E.; H. E. Applegate, G. Bach, H. Basch, J. Bernstein, J. Schwartz \& F. L. Weisenborn: A new class of semisynthetic penicillins and cephalosporins derived from D-2-(1,4-cyclohexadienyl)glycine. J. Med. Chem. 14: 117 119, 1971

5) Actor, P.; J. V. Uri, L. Phillips, C. S. Sachs, J. R. Guarini, I. Zajac, D. A. Berges, G. L. Dunn, J. R. E. HOOVER \& J. A. WeISBACH: Laboratory studies with cefatrizine (SK\&F 60771). A new broad-spectrum orally-active cephalosporin. J. Antibiotics 28: 594 601, 1975

6) Chauvette, R. R. \& P. A. Pennington: Chemistry of cephalosporin antibiotics. 30. 3-Methoxy- and 3-halo-3-cephems. J. Med. Chem. 18: 403 408, 1975

7) Zak, O.; W. A. Vischer, C. Schenk, W. Tosch, W. Zimmermann, J. Regös, E. R. Suter, F. Kradolfer \& J. GELZER: CGP 9000: A new orally active, broad-spectrum cephalosporin. J. Antibiotics 29: 653 655,1976

8) BuCK, R. E. \& K. E. PRICE: Cefadroxil, a new broad-spectrum cephalosporin. Antimicrob. Agents Chemother. 11: 324 330, 1977

9) Yamanaka, H.; T. Chiba, K. Kawabata, H. Takasugi, T. Masugi \& T. Takaya: Studies on $\beta$-lactam antibiotics. IX. Synthesis and biological activity of a new orally active cephalosporin, cefixime (FK027). J. Antibiotics 38: 1738 1751, 1985

10) Hermann, B.; U. D. Treuner, H. J. Schneider, M. G. Young \& H. I. Basch: Diastereomeric 7-ureidoacetyl cephalosporins. I. Superiority of $7 \alpha$-H-L-isomers over D-isomers. J. Antibiotics 31:546 560, 1978

11) Tomatsu, K.; S. Ando, S. Masuyoshi, S. Kondo, M. Hirano, T. Miyaki \& H. Kawaguchi: In vitro and in vivo evaluations of BMY-28100, a new oral cephalosporin. J. Antibiotics 40(8), 1987, in press

12) Leitner, F.; T. A. Pursiano, R. E. Buck, Y. H. Tsai, D. R. Chisholm, M. Misiek, J. V. Desiderio \& R. E. KessLer: BMY-28100, a new oral cephalosporin. Antimicrob. Agents Chemother. 31: 238 243, 1987

13) Litchfield, J. T. \& F. Wilcoxon: Simplified method of evaluating dose effect experiments. J. Pharmacol. Exp. Ther. 96: 99 113, 1949

14) WeiR, N.G. (Glaxo): 3-Vinyl-7 $\beta$-(2,2-disubstituted acetamido)cephalosporins. U.S. 3,994,884, Nov. 30, 1976 